\title{
Analyzing the Relationship Between Car Generation and Severity of Motor-Vehicle Crashes in Denmark
}

Rich, Jeppe; Prato, Carlo Giacomo; Hels, Tove; Lyckegaard, Allan; Kristensen, Niels Buus

Publication date:

2013

Link back to DTU Orbit

Citation (APA):

Rich, J., Prato, C. G., Hels, T., Lyckegaard, A., \& Kristensen, N. B. (2013). Analyzing the Relationship Between Car Generation and Severity of Motor-Vehicle Crashes in Denmark. Poster session presented at Transportation Research Board 92nd Annual Meeting, Washington DC, District of Columbia, United States.

\section{General rights}

Copyright and moral rights for the publications made accessible in the public portal are retained by the authors and/or other copyright owners and it is a condition of accessing publications that users recognise and abide by the legal requirements associated with these rights.

- Users may download and print one copy of any publication from the public portal for the purpose of private study or research.

- You may not further distribute the material or use it for any profit-making activity or commercial gain

- You may freely distribute the URL identifying the publication in the public portal 


\section{AND SeVerity of Motor-Vehicle Crashes In Denmark}

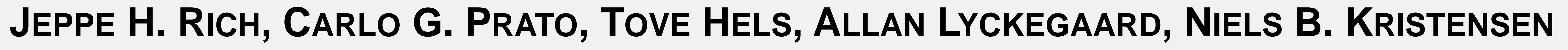 DTU - TECHNICAL UNIVERSITY OF DENMARK}

Transportation Research Board Annual Meeting - Poster Session 724 - January 16, 2013

\section{Background}

In Denmark, road fatalities are on the decrease. This is due to legislation changes, enforcement measures, technological enhancements, infrastructural improvements and human

factors. However, research has not investigated the contribution of each factor to the significant road safety improvement.

Aim

To assess the relationship between car generation and conditional accident severity of drivers in car crashes in Denmark.

Method

Crash severity is recorded in four naturally ordered categories:

- No injury/material damage (1)

- Light injury of driver (2)

- Severe injury of driver (3)

- Death of driver (4)

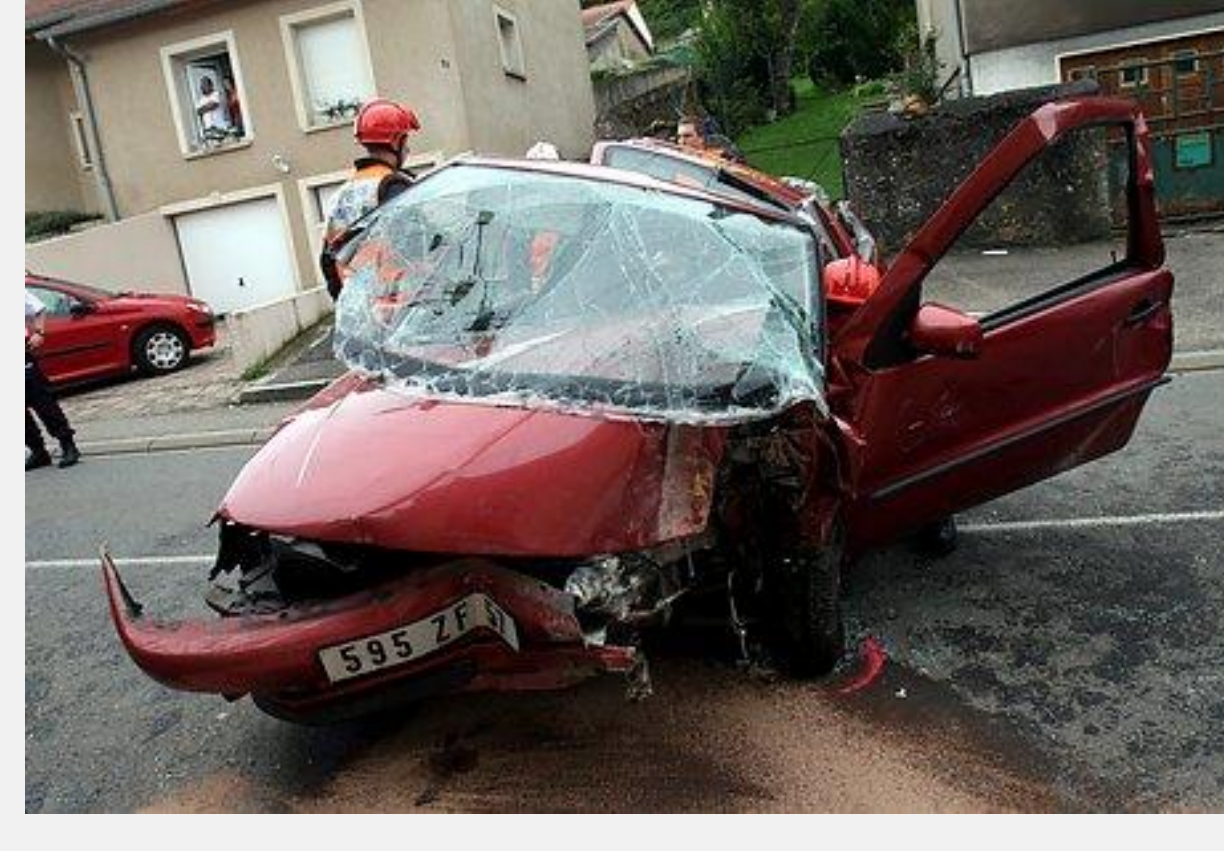

Because of the ordered response discrete variable, an ordered logit-model approach was chosen with a relaxation of the proportional odds assumption:

$$
P\left(y_{i}>j\right)=\frac{\exp \left[\alpha_{j}-\left(X_{i}^{\prime} \beta+T_{i}^{\prime} \gamma_{j}\right)\right]}{1+\exp \left[\alpha_{j}-\left(X_{i}^{\prime} \beta+T_{i}^{\prime} \gamma_{j}\right)\right]} \quad j=1, \ldots, J
$$

Where $P$ is the probability of having an accident with a driver injury greater than $j$ given that the accident has happened. The probability of occurrence of severity category $j(1,2,3,4)$ relates to a vector $T_{i}$ of observed explanatory variables for which the proportional odds asumption does not hold and to a vector $X_{i}$ for which the proportional odds assumption does hold. A Brant test investigated whether the variables violated the proportional odds assumption. $\alpha_{j}, \beta_{j}$ and $\gamma_{j}$ were estimate by maximum likelihood in Stata.
Data

In the analysis we included drivers of passenger cars and vans in police-recorded accidents in Denmark in the period 2004-2010. Thus we included:

- 80,502 observations of drivers in 49,405 accidents (single + multiple vehicle accidents)

- Driver injury as the response variable

- The following explanatory variables:

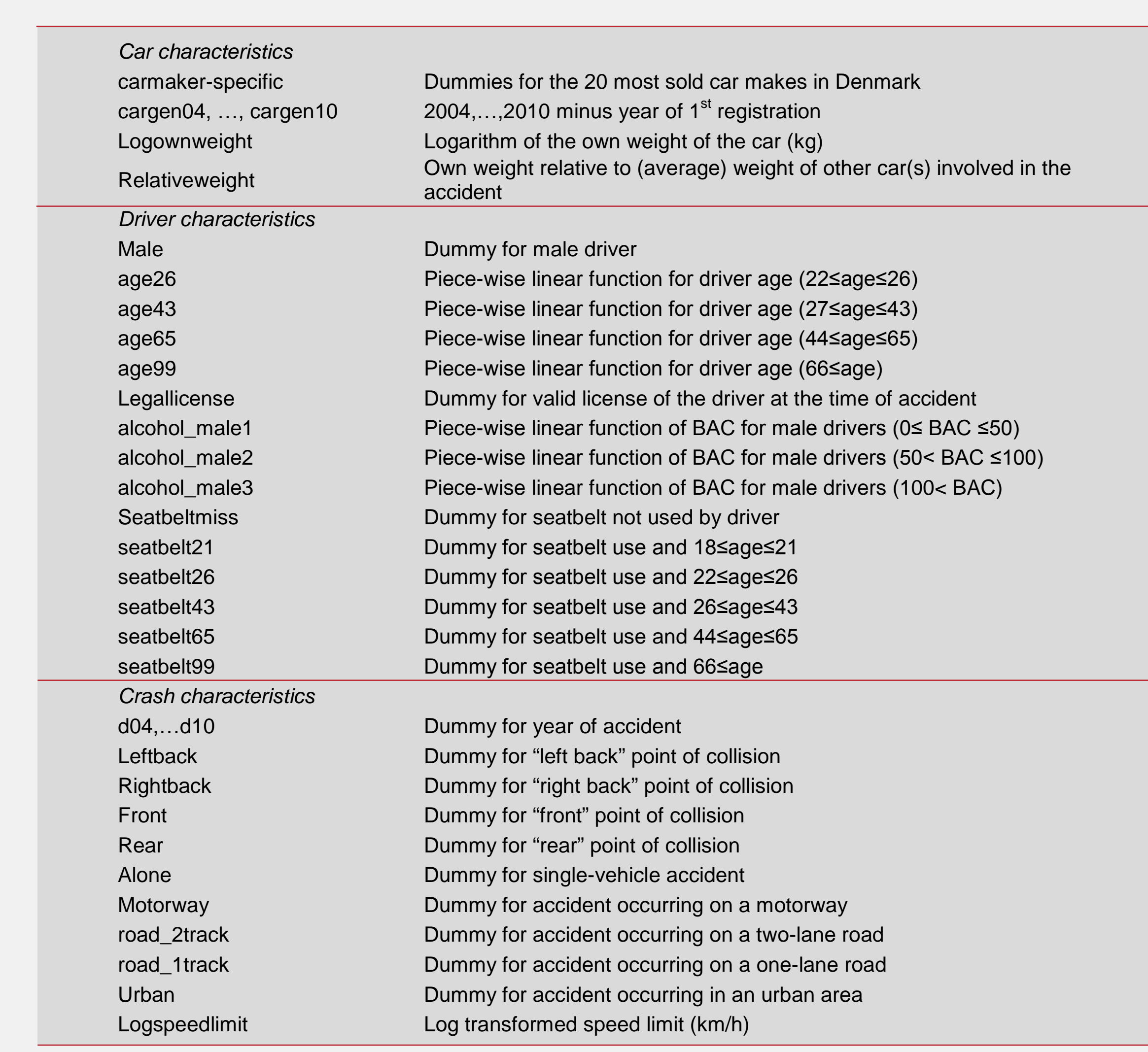

The explanatory variable of main interest was car generation; the rest of the variables correct for conditions related to the driver, the vehicle and the accident.

Results

Associated with the most severe driver injuries were:

- Older cars, lighter cars.

- Higher car speed proxied by the speed limit.

- Older drivers and female drivers.

- A blood alcohol concentration above 1.0 (male drivers).

- Single-vehicle accidents.

- Accident on rural roads as opposed to motorways

(freeways) and urban roads.

- Frontal collisions

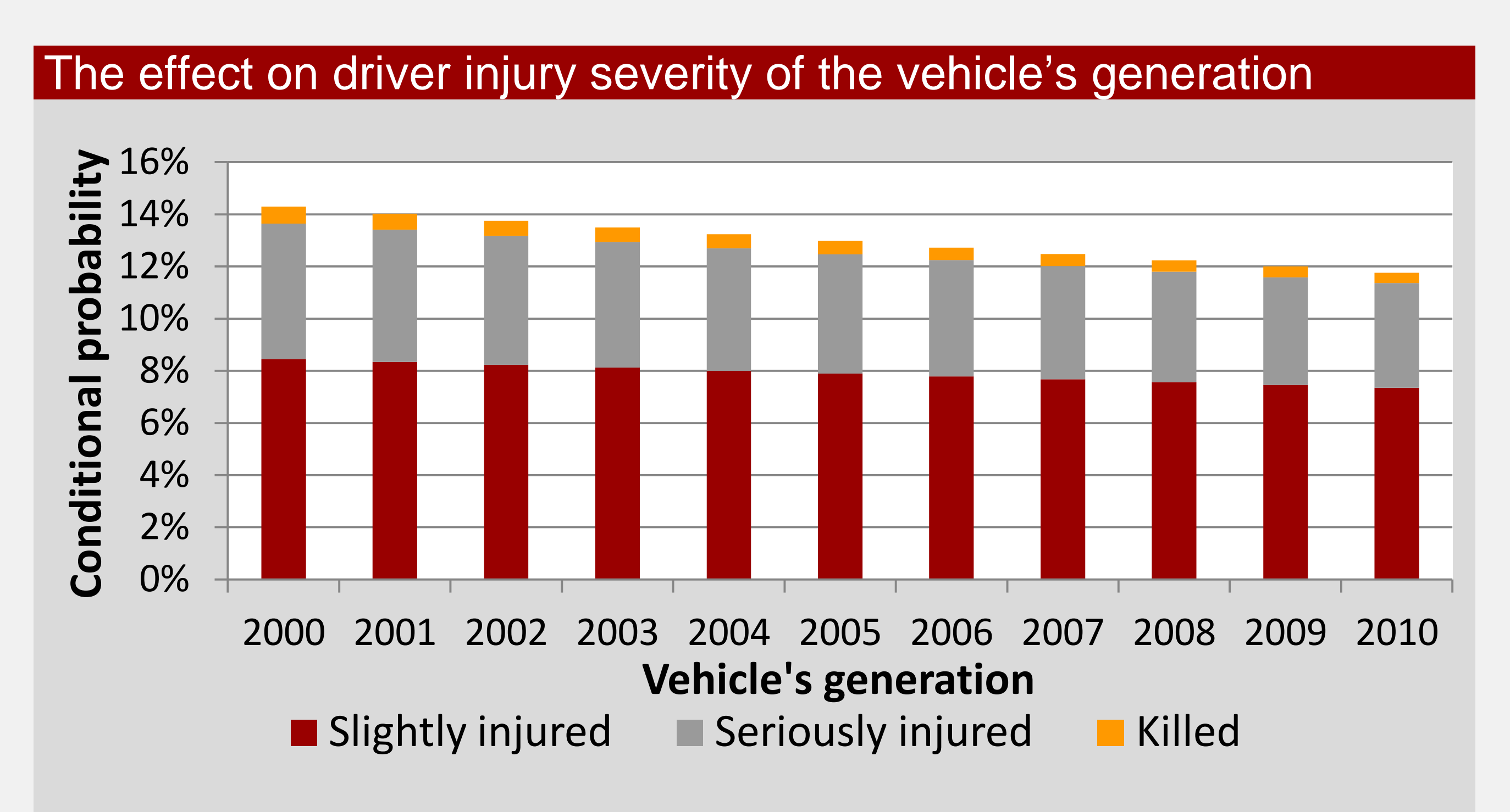

- Newer cars: lower probability of driver injury or death

- Newer cars: higher probability of material damage only accidents (not shown)

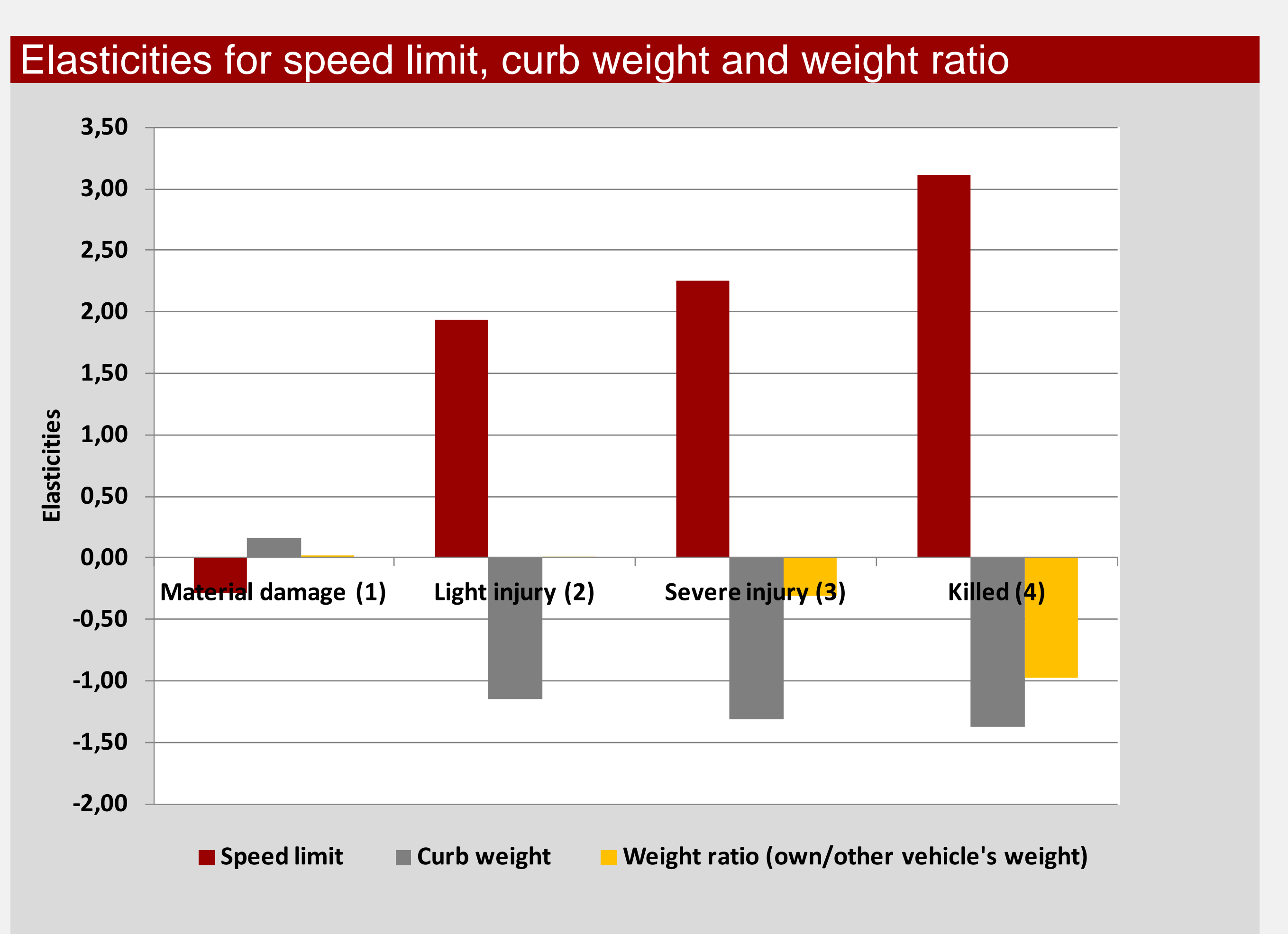

- Higher speed (limit) in accident: higher probability of driver injury or death (red bars).

- Heavier car: lower probability of driver injury or death (grey bars)

- Heavier car relative to the other car in accident: lower probability of driver injury or death (yellow bars).
Scenarios

To illustrate the relations found we calculated the lives and injuries saved if older cars were removed and hypothetically redistributed proportionately among younger cars:

\begin{tabular}{|c|c|c|c|c|}
\hline \multicolumn{2}{|c|}{ Driver injury severities, accidents fro } & \\
\hline ? & Fatalities & $\begin{array}{r}\text { Severely } \\
\text { injured }\end{array}$ & $\begin{array}{l}\text { Slightly } \\
\text { injured }\end{array}$ & $\begin{array}{l}\text { Material } \\
\text { Damage }\end{array}$ \\
\hline $\begin{array}{l}\text { asis model } \\
\text { alculation (real life) }\end{array}$ & 642 & 4,659 & 7,168 & \\
\hline $\begin{array}{l}\text { enario 1: \# cars > } 10 \\
\text { ars reduced by half }\end{array}$ & 571 & 4,401 & 6,980 & 68,550 \\
\hline $\begin{array}{l}\text { Difference } \\
\text { Dind }\end{array}$ & -71 & & -188 & \\
\hline $\begin{array}{c}\text { Differe } \\
\text { nerc }\end{array}$ & $-11.1 \%$ & $-5.5 \%$ & $-2.6 \%$ & $0.8 \%$ \\
\hline $\begin{array}{l}\text { percentage } \\
\text { Scenario 2: \# cars > 15 } \\
\text { years reduced by half }\end{array}$ & 607 & 4,537 & 7,083 & 68,275 \\
\hline Difference & 36 & & -85 & 43 \\
\hline $\begin{array}{l}\text { Difference in } \\
\text { percentage }\end{array}$ & $-5.5 \%$ & $-2.6 \%$ & $-1.2 \%$ & $0.4 \%$ \\
\hline $\begin{array}{l}\text { Scenario 3: \# cars > } 20 \\
\text { years reduced by half }\end{array}$ & 631 & 4,624 & 7,146 & 68,100 \\
\hline & & & -22 & 68 \\
\hline $\begin{array}{l}\text { Difference in } \\
\text { percentage }\end{array}$ & $-1.8 \%$ & $-0.8 \%$ & $-0.3 \%$ & $0.1 \%$ \\
\hline
\end{tabular}

The results indicate that when correcting for a number of variables relating to the driver, the vehicle and the accident, a clear safety potential by renewing the car fleet remains. The potential is probably even larger than indicated here since this study only analyzed potential in injury reduction given that the accident had happened (conditional severity). Renewal of the car fleet will most likely reduce the number of accidents as well, since newer cars are more likely to have more active safety equipment than older cars. Moreover, by including the effect of newer cars on passenger injury, the safety potential would be even larger.

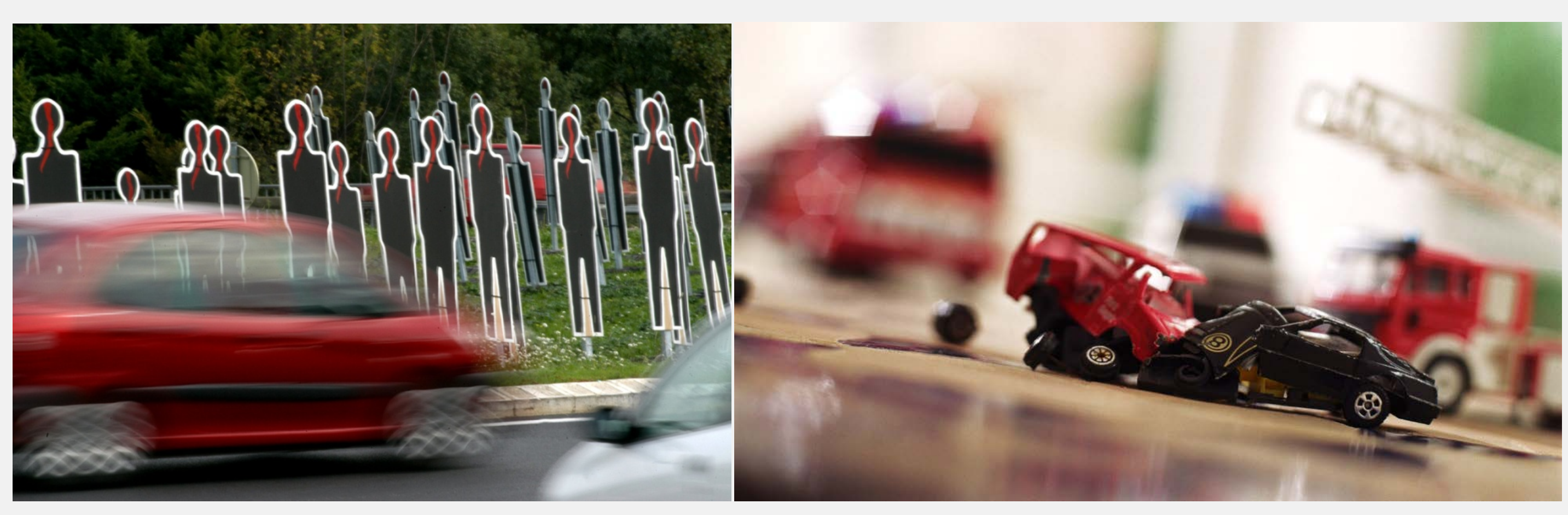

